\title{
The new Labour Code in Hungary in the mirror of the regulations of the European Union and EU member states
}

\begin{abstract}
This article critically reviews the new Hungarian Labour Code from the perspective of the changes it makes to workers' rights compared to previous versions, as well as in the context of the labour law legislation framed by the European Union and that which applies within a range of other EU member states. The author reviews collective and individual labour law, as well as the law on contractual change and working time; wages and allowances; the termination of employment as a result of redundancies; and new forms of work relationships. The rationale has been that labour de-regulation will create job opportunities, but the author points in response to the undermining effect of insecurity at work on morale and competitiveness, having effects also as regards the state budget, as well as on the likely increased trend of the emigration of skilled labour following a cheapening of the domestic price of their labour. It is to be feared that the new Labour Code will, in such circumstances, act not as a means of crisis management but rather as a crisis-raising element.
\end{abstract}

Keywords: labour law, interest representation, trade unions, minimum labour standards, two-circle Europe, representation rights, collective agreements, migration, welfare state, deregulation, competitiveness, crisis management

Introduction

The Constitutional Committee of the Hungarian Parliament held a conference on 22 May 2011 about its Proposal for a new Basic Law, where my task to give a lecture evaluating the proposals in the new Basic Law on the rules of employment. In the lecture, which appeared in the conference volume, I suggested that, on the one hand, it should be laid down in the Basic Law, similar to the German Grundgesetz, that Hungary is a constitutional democracy; on the other, similarly to the basic laws of west European countries and the US Constitution, the opinion of interest representation organisations should be asked for before acts were passed which involved a wide range of classes in a society.

None of my proposals was included in the new Basic Law; moreover, the government discussed the Proposal for the new Labour Code only with the interest representation organisations of employers, sitting down to negotiate with the trade union confederations only after they had forced the government to do so by different demonstrations and other forms of pressure. However, these enforced negotiations brought few results on behalf of employees. It should be mentioned here that, in July 2012, 
during the modification process of the then prevailing Labour Code, Act No. XCIII dissolved the National Interest Reconciliation Council, thus setting down the legal grounds for the government to present a proposal to parliament without having had a tripartite reconciliation of that proposal with the social partners.

Before evaluating - using a legal-comparative method - the new Labour Code, I think it is reasonable to point out that, two years ago, I examined how, after the Maastricht Summit in 1991, the directives of the European Economic Community were exchanged and altered by the new directives of the European Community and how the first directives of the European Union were modified by new directives. I established that the new directives - almost without exception - had reduced the social minimum standards protecting employees' interests. These aggravations were not just taken on by the old member states of the European Union; the new European Union member states were forced to take them on either by the European Union or by the IMF, almost without any modification. It seems that Immanuel Wallerstein was right when he talked about the formation of a two-circle Europe, where the inner circle is the neo-coloniser and the states belonging to the outer circle are the neo-colonised.

The new Labour Code may be examined from this aspect, based on my previous legal-comparative partial analyses, considering that I have already made detailed comparisons of the main labour law institutions with the solutions of the member states, publishing these in many recent works. On this basis, an evaluation may be given now as a kind of synthesis of the main headings of the legal aspects of the new Labour Code.

\section{Collective labour law}

I do not consider it proper that Act No. XCIII as of 2011 abolished the National Interest Reconciliation Council (hereinafter referred to as NIRC), an institution known also in the Benelux and Latin states and in France, as well as, among the new member states, in the Czech Republic and which had once been named by the first FIDESZ (Hungarian Civic Union) government the National Labour Council, similar to the Belgian institute. The National Interest Reconciliation Council was established as an opinion-giving organisation in which all social organisations, public bodies and church organisations were represented, although among them only the participation of the labour organisations was subject to conditions of representativeness, which is therefore discriminatory and not in compliance with the regulations of the European Union.

If the government had discussed its proposal for the NIRC with its coalition partners, trade union demonstrations and social tension could have been avoided. Moreover, it would have been worth remembering, in connection with the abolition of the NIRC, that the NIRC was able to make general tripartite collective labour agreements through which - because of their quasi-legal character, and according to the practice of the European Court of Justice - the directives of the European Union may be integrated into the national law of the member states. This is one of the reasons why it would be reasonable to re-establish the NIRC as a national labour council and to abolish the previous bureaucratic rules placed on it by Act No. LVIII of 2007, which had legitimately fulfilled a legal gap in the meantime. In my opinion, the bureaucracy-free Spanish model would be the best solution to revive national interest reconciliation. 
Concerning the rights of trade unions, these have also been cut down strongly by the new Labour Code. The new Labour Code does not secure the status of trade union officials; neither does it mention the trade union right of objection - with the power of delay - and which was possible to be brought before a labour court, pursuant to the old Labour Code, against an employer's measures affecting a larger group of employees in the case of, amongst others, an increase in work norms associated with a performance-based pay system; nor does it rule whether a trade union may represent one of its members before the labour court in a case against the employer. Neither does the new Labour Code rule whether - in accordance with practice and regulations up to now - the employer shall bear the costs of operation of trade unions or, moreover, whether the employer should put company premises at the disposal of trade unions after working hours or whether trade unions - similar to the situation in the UK and Ireland - are compelled to hold member consultations in restaurants and pubs near the company.

For the sake of legal security, it would have been reasonable to arrange these questions in the new Labour Code, too, like in most member states belonging to the continental legal system.

The problem regarding collective agreements is that, whereas s. 277(3) declares the principle of Günstigkeitsprinzip ${ }^{1}$ as a main rule, like the law of most older member states, s. 283 cancels that by permitting a general divergence from a collective agreement which may even be unfavourable to the employee. Nor is it clear in the new Labour Code whether only one, or more, collective agreements may be concluded at a company. Concerning this, it is a problem that s. 276(2) says only that a trade union with a representative rights is entitled to conclude a collective agreement. Representative rights may be established with a membership of $10 \%$. If such a trade union with this kind of membership level were entitled to conclude a collective agreement in the name of, but contrary to, the majority, it would be rather undemocratic. On the other hand, another version may be that the new Labour Code, in bringing the older regulation to an end should - similar to the UK law - make it possible for all trade unions with representation rights at a company to conclude their own collective agreements as regards their members. In this case, more agreements may be effective simultaneously within a company. This question should have been dealt with.

It is also not clear whether a collective agreement may be extended and, if so, upon what conditions. The old Labour Code regulated this question in a similar way to most west European countries. It is positive that, according to the new regulations, a collective agreement needs to be concluded in writing, but it is unfortunate that the registration of the agreement still takes place at national level instead of at the level of the county/ town where the agreement is signed, and by the local labour agency, since the National Labour Agency is unable to check the legality of collective agreements as regards social dumping.

The new Labour Code makes no changes to the system of the rights of works councils. Therefore, jurisdiction over collective decisions remains rather restricted and formal, although it would be proper if collective decision jurisdiction covered, similarly

1 Under which workplace agreements are free to improve upon the labour standards set down elsewhere. 
to the law of most west European countries, the most important questions of employment relations, such as payment according to performance, working hours, rest periods, holidays and work and health protection. On the contrary, the works council's opiniongiving rights have been limited since, in the case of payment according to performance, work norms may be increased by the employer without the need to approach the works council.

The modification according to which - similar to the German model - candidates are set by committees instead of trade unions during an election to a works council is acceptable; however, it would be proper to make it possible for a representative of the trade union to take part in meetings of the works council in an ex officio capacity and with the right of consultation.

However, I consider it an inadequacy of the wording of s. 236 that it states only that a works council shall be elected if the number of employees in a workshop, or unit, exceeds fifty; it says nothing about what happens when the number of employees reaches fifteen.

Furthermore, s. 269 focuses only on the shop steward by name, but the new Labour Code does not even mention how the shop steward functions, or when he or she is elected, although this question is regulated in detail by all old member states. ${ }^{2}$

Individual labour law

Among the rules applying to the conclusion of employment contracts, we can see that information given verbally has to be submitted in writing within fifteen days instead of the previous thirty-day interval, which is in favour of the employee. However, the list of essential elements of employment contracts still does not contain who practises the rights of the employer and, as regards payment, only the basic salary must be fixed; other regularly-received supplements still do not have to be set - as opposed to west European legal systems. ${ }^{3}$

\section{Modification of employment contracts}

The new regulations of the modification of the employment contract are an advance compared to the old Labour Code.

According to the new regulations, in the case of a legal successor to the employer, which is mostly connected with the sale of a company, a factory or a unit, the employee has the right to choose whether he or she wants to work for the new employer or stay with the old one. Moreover, the new employer takes on guarantor liability for unpaid salaries except in the case of a company takeover within the framework of bankruptcy proceedings, when the payment guarantee fund is liable for an amount of up to three months unpaid salaries and retrospectively for one year.

2 Prugberger, T (2010) 'National, Sectoral and Regional Interest Reconciliation de lege lata and de lege ferenda' Miskolc Legal Review 2: 5-12.

3 Prugberger, T (2011) 'The Basic Rights and Obligations arising from the Employment Contract and Employment Relations in the Recodification Draft of the Labour Code' Economic Life and Society I-II: 269-287. 
The regulation of the old Labour Code, according to which a successor employer was liable for the unpaid salaries of the old employer only if it held a $50 \%$ stake in it, was in sharp contrast to the regulations of European member states.

A period of transfer, substitution, posting, secondment or delegation of an employee is regulated in the new Labour Code as a temporary modification of the employment relationship in compliance with the 'Posted Workers' Directive, whereas the old Labour Code treated it as an employer's order. The new Labour Code - contrary to the old one, which was to the favour of employees - limits posting, secondment or transfer jointly and severally to only 44 days per year, eliminating the previously jointly used 110 days and the possibility of a two-month transfer. At the same time, the new Labour Code does not even mention the possibility - regulated in the Directive - for the prolongation of a posting, secondment or transfer for a further year. Thus it eliminates the possibility of employers keeping employees temporarily without suffering losses and with the possibility of taking them back at any time. In this respect, the new Labour Code does not support employment; on the contrary, it facilitates unemployment. That the new Labour Code does not refer to postings abroad, even indirectly, points in the same direction.

In the sphere of the obligatory modification of the employment contract, it is the case of the pregnant female employee, and the employee who is a mother with small child or children, who stand out. In the case of a pregnant employee, the aggravation as compared to the old Labour Code is that, if the pregnant employee has to be exempted from work, the employer has to pay her not the average salary but only the basic salary. This is a rather fair modification in favour of the employer. However, when the demographic situation is as poor as it is today, in order to improve the position, it would be reasonable if the labour office was ex lege obliged to complement the basic salary to the level of the average salary out of the financial aid fund.

There is, however, a very good development in the new Labour Code under which the employer is obliged to employ a mother coming back to work from parental leave or child care leave on a part-time basis on the request of the mother and up until the child is eight years old. According to the old rules, the employer was able to refuse this kind of request and, therefore, the mother of a small child had to leave her job.

There is also the institute of the so-called Anderungskündigung, ${ }^{4}$ under which the employer terminates the employee's employment with the offer of an alternative job and, if the employee does not accept it, the termination becomes effective. This solution within the German law has been taken up by the Austrian, French and Polish labour law, too. With this in mind, the regulation of the continuing modification of the employment contract and job transfers, which are both otherwise dependent on agreement between the parties, may be overcome.

Chapter VIII of the Code refers to the performance of the employment contract. This Chapter, as compared to the old Labour Code, is much shorter and has been made so empty that this has resulted in total legal uncertainty for employees, as well as a degree of their subordination. Pursuant to the old Labour Code, should an employer give an inaccurate or unprofessional order, the employee is obliged to call the employ-

4 Notice of dismissal pending a change in the contract of employment. 
er's attention to that but must act according to the order if the employer nevertheless insists on it. The old Labour Code regulated such a procedure on behalf of the employee. The new Labour Code does not invoke such a rule at all and says only that the employee is required to act according to the orders of the employer. At a stroke, the employee has become totally defenceless against the employer, a development which is capped by s. 8(3) which says that the freedom of speech of the employee may be restricted, in a way and with what content in mind as - according to the last part of s. 9(2) - may be determined by the employer. In contrast, according to the legal position in the old member states of the European Union, either established sources of labour law or stable judicial legal practice, appearing in authoritative ruling, may assure the right of the employee to criticise as a means of improving working conditions.

This can be applied to this issue, too. This problem should have been included in Chapter VIII, entitled 'The Performance of the Work Contract', which could have been applied to the specifics of the questions referred to here concerning freedom of opinion but which were described only in Chapter I, entitled 'Introductory regulations'.

It might also be mentioned - in this same context - that the employee's obligation to provide personal data, which is also encompassed within this Chapter, may be determined by the employer under the new Labour Code albeit in a way which is similar to the old rules. According to the old Labour Code, the works council's opinion had to be asked for by the employer, but this obligation no longer exists even though in most older EU member states the employer is obliged to co-determine, together with the works council, the extent of personal data which must be provided by the employee.

\section{Working time}

The subjects of working hours, rest periods and holidays are the most troublesome questions in the new Labour Code.

Act No. XCIII of 2011 increased ordinary working hours to 44 hours compared to the 40 which is determined by the Working Time Directive, although it is true that this is for an eighteen month transition period and on the condition that these additional four hours will count as extraordinary working hours, with increased overtime rates.

This seriously damages employees' interests for two simple reasons. On the one hand, the employer may deprive the employee of three-quarters of an hour without having to pay allowances and, on the other, allowances would be owing only in the case of a further four hours additional work per week. It is not by accident that a schedule of three sets of eight hours has been developed in connection with the working day in which eight hours are for work; eight hours are for post-work recreation; and eight hours are for relaxation.

Enforced work, at the expense of both recreation and relaxation, makes the worker's mental and physical regeneration more difficult and leads to the wearing out of the worker ahead of time. All this results in a nervous and physical burden, as well as a decrease in work effectiveness and quality because of the loss of staying power - which is disadvantageous for the employer, too - and which may even lead to break-downs and incapacity for work. All this - as a consequence of an easy setting-in of workplace diseases and possible incapacity for work, especially if this becomes chronic - may charge the state budget very strongly because of the increased expenditure on health 
and retirement insurance and social financial aid. In order that workers may be able to work continuously, in a good physical condition and efficiently, it is important that their thoughts are occupied by other things than just work and that they are suitably rested, as well.

Employment policy and the labour authority are not only responsible for job creation and the encouragement of employment, but also for preventing the workforce from suffering from exhaustion. In regard to this, I disapprove of s. 92(2) which, similar to the old rules, makes possible a regime of twelve working hours per day in the case of jobs involving standby or other similar duties.

In contrast to the diplomatic definition of the Act, in the case of forms of work in which the framework of working hours may be increased by collective agreement, namely in the case of workplaces operating in shifts - either continuously, seasonally or where economic efficiency may not be assured in another way due to production technology - the framework of working hours which is determined, as a main rule, in blocks of four months or 17 weeks, may be prolonged to six months or 26 weeks.

This is a more favourable solution compared to the one in the June draft of the new Labour Code and especially compared to what applied in the old Labour Code; however, as opposed to the solutions of the old, inner circle member states, we can say that, in most of these, the framework of working hours is determined within weeks, even compared to the reference period set down in the Directive, and generally is not longer than one month. The situation is the same as regards overtime. The member states of the inner circle, almost without exception, restrict overtime to a maximum period per week, but the new Labour Code - similar to the old one - prescribes a maximum limit of 250 hours per year, which may even be increased up to 300 hours by collective agreement. All this is allowed by the Directive, notwithstanding that, in member states belonging to the inner circle of the European Union, weekly overtime is, even today, restricted in a similar way to the 1992 Labour Code which restricted its maximum time per week in the initial period.

As regards both standby and duty forms of employment, s. 110(4) of the new Labour Code - as opposed to the old Labour Code - does specify precisely what is meant by standby and duty: in the case of standby, it is the employee who determines where he or she stays, although he or she is obliged to be available for work; in contrast, in the case of duty, it is the employer who determines where the employer must stay.

Concerning the regulations set down in ss. 111 and 112 of the new Code - which maximise the time of duty per 24-hour period and prescribe that such periods shall be counted towards ordinary and extraordinary working hours; and, in the case of standby, that such periods, which may not exceed 168 hours per month, must be taken into account in average working time - it seems that the legislator has taken into consideration the three decisions of the European Court of Justice passed on this subject. The Court has pronounced that periods of standby shall be counted proportionally, while the whole period of a duty shall be taken into account as ordinary working hours. This pronouncement is completely in compliance with the principle of 'from door to door' in the US, according to which the employer is obliged to pay employees the full payment due for ordinary working hours for the whole time since they entered the place of work up to their departure, regardless of whether they were on duty, on standby or actually 
worked there. In contrast, in Hungary the employee is paid much less for duty or standby than for work; we return to the system of the payment of allowances in such situations later in this article.

To sum up, we can say that, except for the temporary increase in weekly working hours - which is basically not in compliance with the rules of the Directive - the regulation of working hours has become more advantageous for employees. This is not the case, however, for workers in public health, where the monthly duty has become 84 hours instead of 72. Many doctors are leaving their jobs not only in Hungary, but also in neighbouring countries, for this very reason and undertaking work in the United Kingdom, the Scandinavian states or Austria. There is a factual case from Debrecen University of Medicine, where a doctor left for work in England because, instead of working for 100 hours in Hungary, there he was obliged to work for only 40 hours and for four times as much salary. Furthermore, he is even able to travel home to see his family for one week per month while, during his work in Hungary, his family rarely even saw him.

Rest breaks in the workplace are regulated by the new Labour Code practically in the same way as in the old one, with a complementary rule according to which such a break may not exceed one hour. This amendment is good in the sense that, when the rest period exceeds one hour, we could rather talk about work being split up over the course of the day.

It is worth mentioning here that both domestic small and medium-sized enterprises and multinational companies are unwilling to give employees the statutory twenty minute rest period after six ordinary working hours or three hours of overtime; and, therefore, employees do not have time either for eating or even fulfilling their biological needs.

The daily rest period - more exactly, the rest period between two working days is determined by the Directive as eleven hours. Similar to the old regulations, however, the rest period between two working days may be shortened to eight hours, while in the case of agricultural seasonal work, it may even be seven hours - which was not allowed according to the old Labour Code. This kind of regulation endangers the biological and mental regeneration of the workforce to a large extent and is thus inhuman. Furthermore, we pointed out above that this is harmful not only for all employees, but also for employers and even the state.

Turning to the weekly rest period then - in compliance with the conditions set down in the old Labour Code - the new version prescribes two days per week, one of which - as a main rule - has to fall on a Sunday. The other rest day does not necessarily have to fall on a Saturday; it may be given on any other day of the week, and they may not even be drawn together. In workplaces operating continuously, both rest days may be given on weekdays, but at least one of them every month shall fall on a Sunday.

This rule is more favourable than that of the Directive since the Directive prescribes a weekly rest period of 24 plus 11 hours; that is, one and a half days, whereas the halfdays - that is, 11 hours - may be drawn together and given adjacent to the 24-hour weekly break. Theoretically, every second Saturday is a rest day; however, it is more the rule in the old member states that workers are on standby rather than working. Therefore, the more workers are employed in a western company, the less time em- 
ployees have to spend on standby. In reality, rest periods at weekends is not less, or only to a small extent so, in west European countries than is the case pursuant to the Hungarian regulations.

At the beginning, the minimum extent of ordinary holiday leave was defined as one month by the Directive and now it is only four weeks. In Hungary, both the old and the new Labour Code specify a basic holiday entitlement of twenty days which - in line with age - is increased by one day for every three, then every two, years until it reaches a maximum of ten days as supplementary holiday. The annual leave entitlement thus reaches thirty days by the age of 45 . Concerning when holidays are given, all but onequarter of the entitlement is determined by the employer. In contrast, in the old member states, the minimum extent of leave is 25-30 days which is further built on by holidays given based on age or managerial position, and even supplemented by skiing holidays in some member states. Moreover, in most countries people do not work between Christmas and New Year's Eve; at most, they are on standby. In this manner, the extent of ordinary holidays in old member states is generally five-six weeks.

In west European countries, the holiday schedule is worked out by the employer in conjunction with the works council after it has been agreed with employees. In Denmark, employees who are unable to take their yearly ordinary holidays during the 'holiday season' are granted more days as supplementary holidays. Besides, in some old member states employees are entitled to a holiday bonus of one month's salary during holidays - either in summer or in winter - with regard that they spend more money on holidays than they would normally. ${ }^{5}$

\section{Wages and allowances}

As regards the regulations contained in Chapter XIII on Payment for Work, the initial problem arises between the connection of minimum wages with performancebased wages. According to the old Labour Code, in the case of performance-based payments the employee is entitled to the full amount of the minimum wage regardless of whether he or she has performed at a level lower than the minimum wage. However, it seems from the obscure composition of s. 137(3) of the new Labour Code that, exclusively in the case of performance-based payments, the wage may drop below the level of the minimum wage if the employee under-performs, and based also on the unilateral decision of the employer. Due to the lack of a precise regulation of this question, the employer may even implicitly decrease pay, without the employee noticing.

It is true that, according to the old Labour Code, the employer suffered a loss as a result of being obliged to pay the minimum wage even in the case of an employee's under-performance. An employer could only remove a 'lazy' employee by way of ordinary or extraordinary dismissal and even then the latter was entitled to demand payment without performance as compensation for damages, though not all labour courts were of this opinion.

5 Prugberger, T (2011) 'The Questions of the New Hungarian Regulations Regarding Working Hours, Rest Periods and Holidays' Law Journal 11: 539-549. 
A good solution would be a middle course according to which, in such cases, a conciliation committee organised within the company or, in the cases of smaller companies, a regional arbitration service officer would determine the lawfulness or unlawfulness of a measure. A party who did not agree with a decision reached in this way could start an out-of-court procedure in the law court against it within five or eight days. The court could make a decision of first instance in such a case within a shortened period of eight or fifteen days.

Another problem in connection with minimum wages is that the government is unwilling to determine a uniform minimum wage, and so different minimum wages are set according to economic-geographical region of the country, economic sector and among professions demanding different levels of education. If minimum wages were to be defined at state level without negotiation with the coalition partners, the differentiation in minimum wages on a regional basis is - in my opinion - clearly discriminatory ${ }^{6}$ however, I think that differentiation in the other cases is also rather disquieting. None of them would be perilous if minimum wages were determined during negotiations taking place in national and regional sectoral, and regional general, committees with the participation of the state. In this case, however, the best solution would be to determine a uniform national minimum wage within the framework of a National Workers' Council as a tripartite agreement, while in the committees it would not be possible to undercut the level thus set. ${ }^{7}$

In connection with wages attached to performance then, according to s. 138 , it is clearly the employer who is entitled to determine them within his or her own level of competence. This means that neither the opinion of the works council nor that of the trade union with representation at the company has to be asked for by the employer. The situation is the same when the employer raises work norms forming the base for performance-based payments. Pursuant to the old Labour Code, in contrast, the employer was obliged to seek the opinion of the works council; thus, this is another question that the employer may decide without reference to the machinery of interest reconciliation. If we compare this with the situation in old EU member states, we can see that, in most, it falls within the machinery for co-decision making, or else falls within the jurisdiction of the works council regarding both questions; and, as concerns the latter, the employer may not neglect taking it into consideration.

The new regulations are rather anti-social on the question of allowances. We could agree with a solution that employees working in shifts, and/or whose workplaces are under continuous operation, are entitled to only $50 \%$ of the allowances for working on Sunday; however, an employee who works in different conditions from these and who is called in extraordinarily for work on a Sunday should be eligible for a $100 \%$ allowance in the same way as employees - otherwise working according to an ordinary work schedule - who work on a bank holiday. It can be concluded from the provisions of s. 143 that those who - on a bank holiday - are working not according to an ordinary work schedule, but who have been summoned to work extraordinarily, are only entitled

6 Thus I am in agreement with the view of Imre Palkovics, the President of the Workers' Council union federation, who has made similar statements.

7 As a result of the principle of Günstigkeitsprinzip (see note 2). 
to a $50 \%$ allowance or to time off in accordance with the employer's decision. The situation is the same in the case of overtime, too, where it is also the employer who decides whether to provide a $50 \%$ supplementary allowance or time off in proportion with the work carried out. In the case of an employee being called in to work on his or her rest day, the employer is obliged only to provide another rest day for the employee without having to pay an allowance.

Allowances for shift work have also changed for employees in a dramatically unfavourable way. Both allowances in the amount of 20 per cent which were paid for afternoon work and for regular night shift work have been ceased. Only employees working in shifts are entitled to allowances for working nights, and then only to onehalf of the 30 per cent that previously applied, i.e. to 15 per cent. According to the rationale of the legislator, such restrictions are in full compliance with the rules in which allowances are determined and paid in west European states. The legislator, however, is neglecting that, in western Europe, this percentage represents a lot higher value allowance than is the case regarding Hungarian wages and salaries.

In line with the regulations effective up to 1 July 2012, trade unions are assuming a $30 \%$ decrease in wages and salaries due to such a drastic fall in allowances. The result is that Hungarian wages and salaries will not reach even one-quarter of west European wages and salaries. Therefore, this kind of payment will, in the future, cover only limited living costs; it will not be sufficient to found a family and educate the next generation.

Thus, the government is putting the country on a downwards path, both mentally and financially. The goal, to create more job opportunities, is welcome. However, the way of achieving it is quite objectionable. In line with the government's concept, foreign companies will settle in Hungary because of the availability of a cheap labour force, similar to the way it happened in the far-eastern 'tigers'. Employment there was, however, quasi-slave work for a pittance, although there was an extension of the workforce.

The skilled Hungarian workforce will not be amenable to this and will migrate to the inner circle of the more developed member states of the EU who are trying to neocolonise the outer circle of EU member states, including central-eastern European member states, and where - due to serious demographic problems - there is an increasing need for a skilled workforce. If this progress continues, only the unskilled workforce, whom western companies do not need, and layers of society who want to live off state benefits will remain in Hungary. All this will lead to a total economic, employment, educational and cultural policy deadlock. In this way, the government will accelerate the elimination of Hungary, in line with the moral philosophical projections of Béla Pokol.

\section{Termination of employment}

As regards regulations concerning the termination of the employment relationship, two highly anti-social concepts have been left out of the new Labour Code. One of these was the possibility of terminating employment in small companies without giving a reason; the other one was the abolition of the protected age before retirement. The first was thrown out by the government itself, because it would not have been in com- 
pliance with the Social Charter; and, as concerns the second, trade unions managed to have this repealed during the reconciliation process. However, the notion of having a protected age before retirement prevails in all west European states.

Nevertheless, the regulations of the new Labour Code relating to the termination of employment are more injurious to the interests of employees in many respects than is the case in comparable west European jurisdictions. This manifests itself right at the beginning of the termination period in the case of ordinary dismissal. In most old member states, the termination period starts not from the receipt of the written notice of dismissal from the employer but from the week following the middle of the month, or from the beginning of the next month. Furthermore, in cases both of ordinary and of extraordinary dismissal, the employer is obliged to listen to the employee and, if he or she is unwilling to change his or her determination to dismiss the employee, he or she is obliged to inform the employee of this informally - that is, orally, during a hearing and prior to the formal notice of dismissal. Such a regulation is missing from the new Hungarian Labour Code.

In connection with the rules on severance pay, the Hungarian solution is, in the case of an ordinary dismissal, more advantageous for employees in that it assures the payment of severance pay ex lege while, in most old member states, this is applied only if the employment relationship is terminated because the employee has grown unfit for work due to health reasons, or because of economic reasons arising from the employer's sphere of interest. Based on practice in western European countries, in other cases, on the basis of a mutual agreement - and even where the employee is given notice of dismissal - severance pay is payable when the employment relationship is terminated, while the amount of severance pay is adjusted to the average salary and not to payments for periods of absence. The new Labour Code has extended this rule both to severance pay and to payments in respect of the termination period.

Turning to provisions on collective redundancy, most west European states still take five people being dismissed as the basis for collective redundancy legislation, even though special protection now comes into effect not from five but from ten employees being dismissed under the Directive regulating this issue. Both the old and the new Hungarian Labour Code follow the Directive in this respect, similar to other new member states. Additionally, west European countries, except for Sweden and the United Kingdom, require the notice of dismissal to be justified socially and, therefore, a redundancy plan is required to be made by the company planning the collective redundancy. Indeed, a social plan is expressively required by the French, German and Austrian statutory labour law regulations; in other states it tends to be judicial practice which requires it. In connection with this, in all old member states except for Sweden, the negotiation period with employee representatives is thirty days as a main rule, although this may be prolonged up to sixty days if necessary while, in the case of a lighter situation, it may be shortened to fifteen days. In most old member states, besides works councils or trade unions representing employees, a representative of the employment (labour) authority may also participate in negotiations with the employer, while the works council has the right to give its opinion on the merits.

It is considered in Hungary to be a collective redundancy situation - as in other new member states - when at least ten employees are to be dismissed. The representative 
of the employment authority may be invited by the employer to the negotiations but, in practice, the authority tends not to be represented. The new Labour Code does not mention the requirement of a social plan, as the old one did; it prescribes only that the goal of the negotiations should be to seek to avoid redundancy or, at least, to reduce it and to mitigate its consequences. At the same time, the new Labour Code shortens the period of negotiation to fifteen days as a main rule, although this may be prolonged up to thirty days.

This means that the legislation refers in vain to how the possibilities of reducing the impact of redundancy must be discussed during negotiations; within such a limited period of time, generally speaking, it is the principle of seniority which prevails in practice. At least the Romanian regulation of such terminations prescribes that, if the economic situation of the company improves and an increase in employment is necessary, the employer is obliged to re-employ employees who were made redundant within the previous year. Such an obligation does not, however, exist in the Hungarian law.

Furthermore, in the case of a collective redundancy situation and dismissals due to economic reasons in general, neither the works council nor the trade union with representation rights in a company has the right to give its opinion, which is a rule that existed in the old Labour Code. Meanwhile, in Holland, no-one can be made redundant without the approval of the works council and the employment agency and, in Germany, from the time of the Hartz reforms, in addition to the collective agreements that exist, in all cases of the termination of employment relationships due to economic reasons but which do not reach the minimum number of employees to be considered a collective redundancy situation, the works council has to be listened to and, moreover, similar to the Austrian law, employee representatives may take the collective redundancy to a court.

With regard to the unlawful termination of the employment relationship by the employer, the primary legal remedy in old member states is, in contrast to the new Labour Code, the principle of in integrum restitutio; that is, reinstatement. Moreover, western laws - similar to the new Labour Code - set a limit on compensation for lost wages and on the usual damages which may be incurred in connection with unlawful termination. At the same time, in old member states the courts assure the possibility of the compensation of the damages actually incurred and are expressly provided even in the United Kingdom (under the compensatory award). ${ }^{8}$

\section{New forms of work relationships}

The new regulations pertaining to atypical labour contracts make the Hungarian labour law more complete and are, at heart, positive. It is very progressive that the new Labour Code significantly broadens the circle of atypical labour contracts, although it is unfortunate that self-employment, which is treated as a 'quasi' employment relationship in western labour law with the application of looser rules other than on the employer's social insurance contribution, has been omitted. Furthermore, the arrange-

8 Prugberger, T (2011) 'The Draft of the New Regulations on the Termination of Employment Contracts' Miskolc Law Review Special Edition: 130-154. 
ment of work as a member of a company (a co-operative, limited liability company or unlimited partnership) is missing.

However, the employment relationship concerning company managers is regulated in a more contemporary way in the new Labour Code, including the setting of a more precise definition of a managerial employee, than hitherto. The only insufficiency is that the hierarchical chain of managerial employees, worked out by Henri Fayol and taken into account in the west, is not mentioned in the new Labour Code. It is also positive that the limited liability of executive employees concerning the negligent omission of their supervisory duty has been omitted: there are no grounds for such a limitation.

It may also considered to be positive that the new regulation does not categorically forbid, in the case of workers who are temporarily transferred to another company, the transferor company from performing intermediate activities; it only prohibits such a company from itself employing transferred workers procured for a consideration. However, it ought to have prescribed that the workers subject to temporary transfer are entitled to the minimum wage, or at least one-half of their wage, even when they are not actually borrowed; but that, if they work - according to the rules of the equal treatment principle - they are entitled to the same wages as other employees. This would have been reasonable to prescribe - similar to the French law - because in such a case there would be fewer possibilities for companies to undertake collective redundancies and transfer their employees to a previously-agreed company, only for the latter to lend them back to the original company at a cheaper cost. Such lease-arranging businesses should have been invalidated ex lege; this would be an advantageous development in terms of employment policy.

\section{Conclusion}

In summary, we would like to state that, in order for the Labour Code to promote competitiveness, efficient forms of work are required. However, efficient work is hindered by a bad working atmosphere, the feeling of being at the mercy of an employer, the fear of dismissal and the fear of a decrease in salary in inverse proportion to the increase in working hours. None of this is likely to raise employment. It is possible that the broadening of job opportunities which the government has prognosticated as an outcome of the Labour Code does indeed take place; however, this will result in the migration of the skilled workforce to neighbouring countries where - due to the demographic crisis - there is an increasing need for workers. Nevertheless, the result of this will be that foreign companies are discouraged from settling their operations in Hungary. It is to be feared that the new Labour Code - in such circumstances - will act not as a means of crisis management but rather as a crisis-raising element. In addition, the powerful limitation of the interest protection role of interest representation organisations, i.e. trade unions and works councils, is likely to intensify this process.

The new Labour Code - in the mirror of international trends and labour law regulations - is disadvantageous to employees while offering an advantage to the employer as regards the principle of equal treatment. This is rather contrary to social protection. This point also appears in the aim of making labour law more like the civil law since, in the latter, motions to decide a claim in favour of one party or the other appear only 
in a co-ordinating way. In civil law relationships, or in legal transactions, in which one party can make use of the other, civil law regulation makes such motions relative; moreover, by the use of legally-binding minimum standards, civil law protects the weaker party. Labour law is a field of law within civil law, so this principle ought to prevail in the new Labour Code, too.

In contrast, and in contradiction to west European labour law regulations, the new Hungarian Labour Code is a mere sketch in many related questions. This can be used, and is indeed likely to be, by employers for their own advantage. Therefore, it will be the primary task of judicial practice to eliminate slipshod work and the gaps created by the legislator based on the principles of the equilibrium of interests and the law, and in good faith and honour.

In conclusion, and as a moral lesson, the best economic situation has always been, and will continue to be, in those west European countries (Germany, Austria, France and the Benelux countries) in which the social market economy and the economic and employment policies of the welfare state predominate to a maximum level. 